\title{
Family mediation in international child abduction cases in Ireland: One size will not fit all
}

\section{Emily Dunne}

\begin{abstract}
This paper explores how mediation can support the legal process in international cross-border child abduction cases in Ireland. It draws on research carried out as part of requirements for a Master's degree in mediation and conflict intervention and reports on qualitative interviews with nine professionals with experience in international child abduction cases or extensive training in this field. It explores the role of the Irish Legal Aid Board's family mediation service in Hague cases and concludes that a 'one size fits all' model is unlikely to meet the need for flexibility in such cases.
\end{abstract}

\section{Key words}

Family mediation, international child abduction, Hague Convention

\section{Introduction}

This paper reports the findings from an MA study carried out as part of requirements for a Master's Degree in Mediation and Conflict Intervention in Maynooth University. The study explored how family mediation could support the legal process in international child abduction cases in Ireland from the perspective of legal and mediator practitioners who are experienced in this field. 
Family mediation has long been established as having a positive role in facilitating communication between separating couples who need to identify and act on their children's needs (McGowan, 2018). According to the Het Mediation Bureau in the Netherlands (2019), research shows that agreements made during mediation are more likely to be accepted and complied with by parents because parents have come to agreement themselves.

Corry (2011) outlines how family mediation in Ireland, which began with practitioners working from just one small office in 1986, had grown to include 16 offices nationwide, just 25 years later. The Irish Legal Aid Board, which provides professional civil legal aid and advice, also offers family mediation as well as managing certain criminal legal aid schemes. It reports that it currently accounts for about 2,500 mediations a year. This represents a 10-fold increase since the Board's early years and clearly demonstrates a growing demand for mediation services from families who find themselves in conflict (Legal Aid Board, 2019).

The Law Reform Commission recognises mediation as an alternative means of dispute resolution (ADR) and a positive method of facilitating separated parents to come to a joint agreement for their families without the need for court proceedings (Law Reform Commission, 2010).

International child abduction cases are considered a priority under the Hague Convention of 1980. The Hague Convention is a multilateral treaty that was sanctioned by the Hague Conference $(\mathrm{HCCH}, 1980)$. The Convention aims to provide a rapid process which enables the return of a child abducted from onemember country to another. The Brussels 11 regulations on conflict of law issues in family law between member states streamlined this process further, incorporating non-Hague countries and European Union countries (Europa, 2005). The Guide to Good Practice of 2012 under the Hague Convention 1980 has sought to ensure that the process for the return of the child to its place of habitual residence is swift and has the full support of the law. 
Each of the countries which signed the Hague Convention 1980 has a Central Authority in place $(\mathrm{HCCH}, 1980)$. Under the Convention, one of the roles of the Central Authority is to help parents to bring applications of cross-border child abduction to the correct authorities. In Ireland, the Central Authority was set up under the Child Abduction and Enforcement of Custody Orders Act, 1991 and is based in the Department of Justice and Equality (Department of Justice and Equality, 2019).

\section{Challenges}

International child abduction places parents in a highly distressing situation. The legal process in place can be an extra cause of distress and the professionals who support parents in abduction cases are very aware of this emotional journey. There is widespread agreement that the legal process should be swift whilst ensuring that the best interests of the child are respected.

The study focused on the challenges of mediation in Hague cases and looks at how mediation links in with the legal procedures as set out in the Convention. This article reports on the views of professionals working with Hague cases in Ireland and their personal experiences and recommendations. It also explores differences between the perspectives of mediators and legal practitioners. The constraints of mediation in the legal sector and the issues involved in applying the Brussels 11 regulations are also discussed in the study (Europa, 2005).

\section{Previous studies}

A study by Kearney (2014) reported that the Legal Aid Board's family mediation services in Ireland was very child-focused and very interested in ensuring the voice of the child is heard in the Hague case process. A study by Foley-Friel (2014) discusses how children can often see the conflict differently from their parents and stresses how this means that the voice of the child is critical to negotiations. Foley-Friel's (2014) study recognises that mediation in family law is the best approach to bringing the parents back to what is best for the 
child. The courts and the legal system have shown that their aim is always to identify and pursue what is in the best interest of the child.

The rights of the child are a key focus in international child abduction cases. The thirty-first amendment to the Irish Constitution in 2012, with the addition of Article $42 \mathrm{a}$, ensured the protection of the rights of the child in law and acknowledged the right of the child to be heard (Foley-Friel, 2014). It is recognised by mediators and parents alike that children can see the family conflict in a different light to them. Kearney (2014) also focuses on the voice of the child in mediation and the importance of meeting their needs throughout. Kearney discusses the ways in which mediation benefits the child in cases of child custody. It is important, therefore, to understand how mediation is applied in practice and how it can be used effectively.

The International Social Services (ISS) is a global NGO founded in 1924. ISS has a presence in over 120 countries where it promotes child protection and welfare. The 2010-2018 report from ISS on International Family Mediation promotes the facilitation of mediation in cross-border child abduction cases. This report also promotes the benefits of connecting mediators from countries around the world so they can share experience and information. This is a positive step towards ensuring the competence of mediators worldwide and it helps to acknowledge and underscore the importance of their role. The ISS works with approximately 75,000 families worldwide each year (International Social Services, 2019).

Thorpe (2018) discusses how mediation is not always considered suitable for child abduction cases. He highlights issues such as the limited timeframe in emergency cases, possible different cultures and languages and how mediation in international cases is still in the early stages. Nevertheless, he concurs that over the past decade mediation has played a part and has become more commonplace within the legal framework. 
According to Paul and Walker (2009), it is now standard procedure in Germany to offer mediation first in cross-border child abduction cases. This is now recommended by the courts and the German Central Authority and is reported to have been very effective.

Vigers, as one of the contributors to the Guide to Good Practice 2012 $(\mathrm{HCCH}, 2012)$, acknowledges the enthusiasm for mediation to support a resolution in Hague cases but observes that, despite legislative changes that have been introduced, not many cases have been referred to mediation and mediation has not been mentioned during the legal process (Vigers, 2011). Her findings are relevant to the present research in exploring how mediation is being accessed and implemented in Ireland. Since 2011, the collaboration between the Legal Aid Board and the Family Mediation Service has offered mediation in family law ( and Lloyd, 2011), but the application to Hague cases has been limited.

Mediation within the legal framework is now more accessible and tools to support this approach are being made more available to the legal profession. The European Commission for the Efficacy of Justice (CEPEJ) includes representatives from all 47 members of the Council of Europe. It has issued a mediation development toolkit as a guide to mediation for lawyers (CEPEJ,2018). This is not specifically about Hague cases but applies to this field of mediation as well as others.

Previous studies discussed did not explore the selection of cross-border cases that have been brought to mediation over the last three years. Nor did they consider the impact of the mediation in court proceedings.

\section{Research participants}

The participants invited initially to participate in the research were mediators working in family mediation services. Mediators who had experience with international child abduction cases or attended specialised training were also invited. The need to invite participants from the legal authorities, as the first line 
of contact in cross-border abduction cases, quickly emerged in the research. Under the Hague Convention (1980), all cases must be dealt with legally through the courts and offered the utmost priority. The Irish Central Authority and the barristers, solicitors, and judges were deemed to be the key individuals in these cases and all were invited to be part of this study. However, due to the limited timeframe, not all were available for interview.

Twelve professionals within the legal and mediator framework in Ireland were invited by email to take part. These invitations were followed up with a personal phone call. Nine participants agreed to be interviewed. A selection had experience of cross-border child abduction cases and others had extensive training in the area.

Other professionals who were invited to be interviewed agreed to meet for an informal discussion but declined a full interview. The information gained at these informal meetings was not included in the study findings, but they contributed greatly to the researcher's understanding of the role of professionals. Individual interviews were held with each of the nine participants over a period of six weeks. No identifying features were used in the discussion other than identifying participants either as mediators or legal professionals.

The decision to invite legal professionals and mediation professionals was informed by the literature review. The aim of the study was to explore how both groups viewed the process of mediation within the legal process of international child abduction. Their personal experiences and observations were critical to the research and contributing to an understanding of where mediation can fit in the justice system and a review of the prospect for development. This cohort of experts from both professions ensured a balanced research study and an opportunity to examine the different perspectives. 


\section{Findings}

The research supported the findings of previous studies in identifying little evidence of family mediation in international child abduction cases in Ireland. However, many of the legal practitioners who had experience of family mediation in a selection of Hague cases over the last three years, now reported that they were more open to involving mediation. Their documented experience with parents and the positive emotional results were the key to their change in attitude to mediation.

Overcoming the many obstacles that were perceived to be in place, such as timing, resources, language and availability of professional mediators, was not considered to be as demanding a task as it was originally perceived and participants were of the view that the benefits achieved outweighed the difficulties. However, they considered that the level of resources of the Legal Aid Board's family mediation service was a cause for continuing concern.

The professionals involved in Hague cases were also in agreement that the timeframe of six weeks, set by the Hague Convention for the completion of cases, was unachievable. On the other hand, this was not seen as an obstacle, but rather a challenge to be dealt with. All professionals were familiar with the delays that can arise and recognised the frustration that this can cause for both the parties and the legal professionals.

The opportunity for legal professionals to attend information and training sessions on mediation in family law had also encouraged them to consider more favourably this method of alternative dispute resolution. All of the respondents concurred with previous studies that mediation is not suitable for all cases, but also agreed that it should be recommended to and considered by the legal practitioners in more cases. Due to the challenges that come with each crossborder child abduction case, an approach tailored to each individual case was deemed to be appropriate. The expression "one size will not fit all" emerged as the shared view among both mediators and legal practitioners. 
According to Savage (2011), the John Haynes 'all-issues' model of mediation continues to be an ongoing model of family mediation for the Family Mediation Service. The 'all issues model' deals with budgets, access and property issues (Haynes et al, 2004). However, this study found that in international child abduction mediation, the main issue is access, thus creating a more discrete model of mediation.

\section{Progress to date in Ireland}

In Ireland, over the past three years, the Legal Aid Board have introduced mediation to a selection of Hague cases which were deemed suitable by the legal professionals. This research recognised the positive approach to the conflicts involved in International child abduction and the desire of all the professionals to support the parents. A very rich discussion evolved from the legal and mediator practitioners and their keen interest for a positive outcome for their clients was wholeheartedly acknowledged. The introduction of mediation into such cases concurs with findings discussed in the literature review on abduction cases that have already involved mediation.

Mediation is now fully recognised as an alternative dispute resolution (ADR) by the Legal Aid Board and the Law Society. Emerging challenges are continuing to be explored by the legal and mediator practitioners as they gain more experience. The Legal Aid Board's family mediation service is proceeding cautiously and the opinion of where, when and how mediation fits into the legal arena is being considered more openly and in line with the Hague Convention Guide to Good Practice (2012) recommendations.

\section{Conclusions}

This study found that the approach of offering mediation early in cases of cross-border child abduction and the court proceedings in Ireland is only in its infancy. Nevertheless, the practitioners agreed that this approach is already 
showing positive results in cases over the last three years. They suggested a review of regulations to ensure a smoother process. However, to fully comprehend the implications of family mediation in international child abduction cases, further research needs to be carried out. Further studies could expand the methodology to include observation of how mediation is approached and established as part of the process. It should also consider the advantages and disadvantages of mediation for parents and children, who are the significant parties in these disputes.

Future research could also include a survey of all legal and mediator practitioners to elicit their views on this topic. The gathering of reactions following completion of any engagement can be very positive but when initial emotions wear away, different views can emerge. Repeating the survey, a year later would provide additional valuable information. The research also suggests a need for longitudinal study following the journey of some of the participants and clients of mediation in cross-border child abduction cases.

This research also discussed the timeframe for case completion of six weeks recommended by the Hague Convention and the view of the professionals that the timeframe was unachievable. According to this study, this timeframe needs to be reviewed.

The opportunity to introduce mediation as an ADR (alternative means of dispute resolution) early in the process was keenly discussed by participants in this study. They suggested including information at the primary stages of the process, such as at the point of Central Authority application. The development of a Public Service model of mediation was also discussed. This would build on the accredited policies and standards of the Mediation Institute of Ireland by adopting domainappropriate terms, conditions and standards and emphasise social responsibility and accountability.

Implementation of these recommendations faces potential challenges such as data protection and legal implications. However, further exploring the concepts may ensure that mediation can become a normal part of the legal process of Hague 
cases deemed suitable by the court. Due to the limited number of these cases that have come to mediation, detailed research has not yet been carried out.

\section{Summary}

The common view of respondents working in the legal and mediation profession was that there is significantly greater scope for use of mediation in international child abduction cases. Further research is needed to engage further with additional interested practitioners.

This study acknowledges that the Legal Aid Board's family mediation services are proceeding cautiously and the position of where mediation fits into the legal arena remains under consideration. Nonetheless, the participants of this study agreed, that when the parents are agreeable, mediation can add value in apposite international child abduction cases.

The work of the Legal Aid Board's family mediation service has contributed to a standardised model of mediation that is used in Hague cases as well as more generally. It was the view of all respondents in the present study that a more flexible model is required and that "one size will not fit all".

\section{References}

Corry, G. (2011) Origins and Policy Development Issues of the Family Mediation Service in Ireland (1986-2011) in Sweeney, D. and Lloyd, M. (eds.) (2011).

Mediation in Focus: A Celebration of the Family Mediation Service in Ireland. Family Mediation Service, Dublin: Glen Print Ltd.

Council of Europe (2018). European Commission for the Efficiency of Justice (CEPEJ): Mediation Development Toolkit - Ensuring Implementation of the CEPEJ Guidelines on Mediation https://rm.coe.int/mediation-development-toolkitensuring-implementation-of-the-cepej-gui/16808c3f52 [Accessed 13 August 2019] 
Department of Justice and Equality (2019). What is the Central Authority and how can you make an application under the Convention http://www.justice.ie/en/JELR/Pages/WP15000137\#4.\%C2\%A0\%C2\%A0\%20\%C2\%A0 What\%20is\%20the\%20Central\%20Auth [Accessed 11 November 2019]

Europa (2005). Brussels 11. Practical Guide for the new Brussels 11 Application. Available at :

http://ec.europa.eu/civiljustice/publications/docs/guide_new_brussels_ii_en.pdf [Accessed 4 December 2018]

Foley-Friel, M.(2014) A Mediator's Reflection on Family Mediation in a Recession. Journal of Mediation and Applied Conflict Analysis, 2014, Vol. 1, No. 2. iv Haynes, JM, Haynes, GL, and Fong LS (2004). Mediation: Positive Conflict Management. Albany: State University of New York Press $\mathrm{HCCH}$ (1980). Convention On The Civil Aspects of International Child Abduction [online] Available at: https://www.hcch.net/en/instruments/conventions/fulltext $/$ ?cid $=24$

[Accessed 11 November 2018]

$\mathrm{HCCH}$ (2012). Guide to Good Practice. Mediation [online] Available at:

https://assets.hcch.net/upload/guide28mediation_en.pdf [Accessed: 14 December 2018]

Het Mediation Bureau (2019). Cross Border Mediation. Available at:

https://www.kinderontvoering.org/mediation/pagina/crossborder-mediation.html [Accessed: 25 August 2019]

International Social Services (2019). Final Report on International Family Mediation Programme (2010 - 2018) Available at: https://www.iss-

ssi.org/images/MFI/Final_Report_on_the_IFM_Programme_2010-2018.pdf (Accessed: 12 August 2019)

Kearney, S., (2014) The Voice of the Child in Mediation. Journal of Mediation and Applied Conflict Analysis, 2014, Vol. 1, No. 2 [online] Available at:

http://mural.maynoothuniversity.ie/5052/7/SK-Voice-2014.pdf [Accessed 11 November 2019] Law Reform (2016) Protection of Children (Hague Convention) Act 2000. Revised. Updated to 18 January [online] Available at: 
https://www.lawreform.ie/_fileupload/RevisedActs/WithAnnotations/HTML/EN_A CT_2000_0037.HTM [Accessed 3 December 2018]

Legal Aid Board, (2019) Draft. Legal Aid Board, Family Mediation Service, Operation and Strategy. 8.4 International Child Abduction cases July 2019.

McGowan, D., (2018). Reframing the mediation debate in Irish all-issues divorce disputes: from mediation vs. litigation to mediation and litigation, Journal of Social Welfare and Family Law, 40:2, 181-194, DOI:

10.1080/09649069.2018.1444445

Paul, C.C. and Walker, J. (2009). An International Mediation: From Child Abduction to Property Distribution, American Journal of Family Law. Vol. 23, no. 3, pp. 167.

Savage, C. (2011) The Evolution of Family Mediation Training in Ireland in Sweeney, D. and Lloyd, M. (eds.) (2011.) Mediation in Focus: A Celebration of the Family Mediation Service in Ireland. Family Mediation Service, Dublin: Glen Print Ltd.

Thorpe, M. (2018) "Mediation to resolve child abduction issues for Hague and nonHague convention countries", Singapore Academy of Law Journal, vol. 30, no. SE, pp. 575-586.

Vigers, S,. (2011), Mediating International Child Abduction Cases: The Hague Convention. Vol. 7. Oxford UK: Hart Publishing

Emily Dunne has an MA degree in Mediation and Conflict Intervention, Edward M Kennedy Institute for Conflict Intervention, Maynooth University and is an Approved Mediator, Mediators Institute of Ireland. 